\title{
Editorial
}

\section{A propósito de un caso}

La noche del domingo 30 de octubre de 1938, a eso de las 8 de la tarde, cuando los americanos se disponían a celebrar la noche de Halloween, Orson Welles comienza la lectura radiofónica de la novela de Herbert George Wells: "La guerra de los mundos". El formato de boletín informativo dio total credibilidad a la narración y provocó situaciones de histeria colectiva y el colapso de parte de Estados Unidos. El pánico se adueñó de los ciudadanos, se formaron comités de autodefensa y nadie dudó un momento que New Yersey había sido invadida por extraterrestres. El resto de la historia es sobradamente conocida.

Periódicamente, aunque algo más tarde que cuando Orson Welles comenzaba su narración, los telediarios suelen informar al mundo de algún revolucionario método o solución mágica para la cura del Cáncer, así, en singular.

Probablemente, los responsables de publicitar la noticia no le concedan más que un valor limitado y su motivación y energía al trasmitirla no sea sino parte del interés en amenizarnos la velada, como el actor americano con sus oyentes. La trascendencia social es menor y nadie sale a media noche al hospital a buscar la pócima. ¿O sí? Detrás de cada noticia hay un ejército de amigos, familiares y enfermos. La repercusión psicológica que tiene sólo se conoce cuando, al día siguiente, llegan varias personas a la consulta preguntando por el remedio. Cuando tu hijo tiene veintitantos años y se está muriendo, todo vale.

La experiencia de terror colectivo tras la lectura de la novela de Wells se repitió en Quito el 14 de febrero de 1949 y el 25 de junio de 1958 en Lisboa. También aquí, de forma periódica se cura "el Cáncer". Son nuevos los receptores del mensaje. Otros los enfermos y familiares que sufren su angustia y desesperanza. Nuevamente, más explicaciones y más desilusión.

¿Se puede hacer algo para evitar esta reverberante situación? Probablemente, no exista ninguna solución que controle el problema completamente. Son muchas las partes abonadas para continuar germinando la siguiente invasión marciana.

Cabría plantearse si más educación social neutralizaría fenómenos paramédicos. Sin embargo, el nivel socio-sanitario de aquellos que acuden reclamándolo es alto, no parece por tanto que ello resolviese demasiado.

Debiéramos preguntarnos si los médicos estamos contribuyendo a la "vulgarización médica" prestándonos demasiado fácilmente a servir de coartada pseudocientífica en foros no médicos o mini-entrevistas de escasos segundos que hacen imposible 
articular una opinión formada. Si, quizá, debiéramos remitir a los medios de manera sistemática y uniforme al respectivo representante de la Sociedad Médica afectada que sirviera de portavoz autorizado. Habrá quien piense que ello podría causar detrimento en la libertad de expresión y que cada uno es libre y suficiente para poder expresar su opinión. Otros renegarán de ver perdido así su minuto de gloria. En todo caso, cabe recordar que el opinar, lógicamente, se hace a título personal, pero como representante de facto de un colectivo determinado, no como individuo.

Si hace sesenta años, la radio fue capaz de crear una atmósfera casi real de invasión marciana, hoy la televisión con medio minuto es capaz de, casi, curar el cáncer. Reclamar seriedad y rigor periodístico debe ir ligado a la obligación de reflexionar sobre nuestro papel en esta nueva obra radiofónica.

Mariano Provencio Director Revista Oncología Servicio de Oncología Médica Hospital Universitario Puerta de Hierro

Madrid 